\title{
Channels of Monetary Influence: A Survey*
}

\author{
ROGER W. SPENCER
}

\begin{abstract}
A
MONG the numerous controversies surrounding "money", few are further from resolution than the issue of how money affects the economy. Compounding the controversy is the fact that the arguments advanced are not divided neatly along so-called monetarist and nommonetarist lines, but are separated by other criteria.

To be sure, monetarists have long taken exception to the intellectual straitjacket of the Keynesian framework which limited the influence of monetary actions to the response of investment to interest rate changes. However, the monetarist alternatives offered have been far from uniform. Certainly, monetary actions result in the change of more than one relative price - the interest rate - and one type of spending - investment. However, substantial disagreement anong monetarists (as well as other economists) persists beyond this point.
\end{abstract}

There is basic agreement that at less than full employment, changes in the rate of growth of the money supply affect ontput and employment before prices, a proposition which may be traced back at least two hundred years (Hume [48]), but this tells nothing about how total spending and its components react to monetary actions. It is necessary to examine the changes in relative prices and wealth associated with monetary impulses to gain insight into the moneyspending relation.

When the existing money stock (however defined) either exceeds or falls short of the quantity demanded, wealth and/or relative prices change and this sets off both substitution and weath effects, as indicated in the acompanying diagram. ${ }^{1}$ The changes in relative

* The author acknowedges the helpful comments on earlier drafts of George Kaufman, Thomas Mayer, John Pippenger, Robert Rasche, William Rawson, Clark Warburton, and William Yohe. They are blameless for remaining errors.

The "correct" definition of money and the determinants of money denand and supply functions are matters closely related to, but beyond the scope of the present article. Another limtation is that because of the large number of authors surveyed, only the briefest of sumparies can be given here. In some cases, this results in considerable oversimplifation of complex analyses.

Substitution and wealth effects are treated here as essentially equivalent to substitution and income effects of generally- prices typically involve changes in the rates of return on real capital and financial assets as well as changes in the prices of goods and services. Ways in which changes in wealth may influence spending include movements in real cash balances and changes in the market value of equities.

There remains considerable disagreement about the relative importance of these factors in the transmism sion of monetary inpulses. This is not surprising, given the history of the relative price and wealth relations. Keynes, as well as prominent economists who prem ceded him, was ambiguous on the subject. This article first traces the early development of these two factors and then analyzes more recent work in each area.

\section{MSTORTCA BACKGROUND}

Among the better early efforts to explain the money-spending linkages were those of Irving Fisher and Knut Wicksell. Writing around the turn of the century, they both maintained a short-run view of the transmission process which was dominated by interest rate movements and a long-run view in which the key role was played by changes in real cash balances $\left(\frac{\text { Money }}{\text { Price Level }}\right)$.

\section{Fisher and Whoksell}

Fisher, like other neoclassical writers, determined that output was at its full-employment level in the long run. In the short (or transitional) run, however, business cycles occurred in Fisher's time, as well as in other periods before and since. Consequently, macroeconomic analysts have continued to attempt explanations of this phenomenon. Fisher's view of the business cycle depended strongly on "sticky" interest rates.:

accepted price theory. Although monetary-induced changes in relative prices or changes in wealth may generate both substitution and wealth effects, the relative price change has often been associated more with substitution effects and the wealth change more with wealth effects; we will follow that practice.

2See especially Fisher"s Chapter 4 "Distarbance of Equation and of Purchasing Power During Transition Periods," in Fisher [25]. In later years, Fisher [24] associated severe swings of the bisiness cycle with changes in debt activity. 


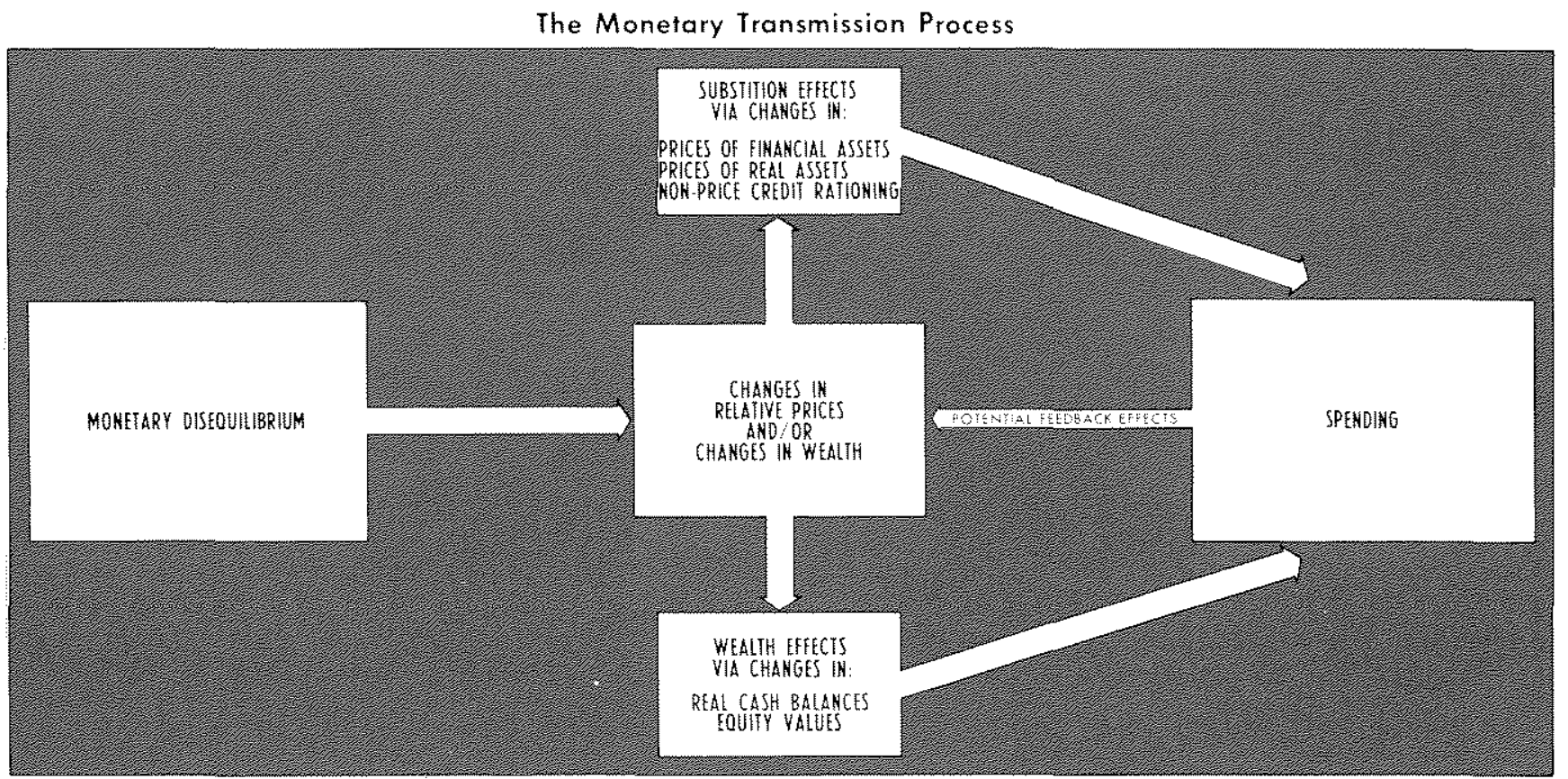

This relative price effect (via interest rates) was set off by an increase in the money stock relative to the quantity of money demanded. The nominal money supply may be assumed to have increased due to a rise in the gold stock and, consequently, bank reserves. With the additional assumption that output and velocity were fixed initially, a rise in the commodity price level was expected to be associated with the money supply increase. Because Fisher assumed that the commodity price rise preceded the increase in interest rates, with interest costs being viewed as a significant component of firms operating costs, the rise in the price level produced an increase in firms' profits.

A continued increase in demand deposits (through business investment loan demand) relative to currency resulted in yet further increases in prices and profits. Eventually, however, excess reserves would run out, the interest rate would become "unstuck" and would rise even faster than commodity prices. With the rise in firms' costs of operation, there would oecur a decline in profits and investment and a sharp in. crease in bankruptcies. The downward phase of the cycle was reversed when excess reserves again rose and the interest rate had fallen accordingly.

Wicksell's well-known "cumulative process" also captured cyclical movements of the economy largely through interest rate changes. Some initial disturbance, such as an innovation or technological breakthrough would foster an increase in the desire to invest at the prevailing interest rate. The demand for loanable funds would then rise as would the "normal" or "natural" rate of interest, the rate "at which the demand for loan capital and the supply of savings exactly agree" (Wicksell [89], p. 193). If, however, the banking community failed to realize that investment demand had risen, they would maintain the same market rate of interest through increases in the money supply which, given the usual classical assumptions, would result in commodity price rises.

Note that at this point the money supply has risen, observed interest rates have been kept low in relation to the normal rate, and business spending has been the component of aggregate demand which has increased. After some period of time, the banks' reserve position deteriorates and monetary growth is curbed. The market rate of interest rises to the level of the natural rate, an action which leads to the elimination of excess aggregate demand and price level increases.

In the above short-run dynamic analyses, both Fisher and Wicksell relied on the relative price mechanism inherent in a money-interest rates-investment framework. However, in their approach to the determination of long-run equilibrium, interest rates and investment were replaced by a treatment of the role of real cash balances.

Fisher's real balance explanation began with an assumed doubling of the money supply: 
Suppose, for a moment, that a doubling in the cur rency in circulation should not at once taise prices, but should halve the velocities instead; such a result would evidently upset for each individual the adjustment which he had made of cash on hand. Prices being unchanged, he now has double the amount of money and deposits which his convenience had talght him to keep on hand.

With the apparent increase in wealth, everyone tries to reduce their cash balances by purchasing goods and services, according to Fisher. Because velocity (V) and output ( $Q$ ) in the equation of exchange $\mathrm{MV}=\mathrm{PQ}$ are determined to be fixed in the long rum, a doubling of the money supply (M) cannot generate any increased holdings of goods and services, but must result in a doubling of the price level $(P)$.

Wicksell also saw real balances as the adjusting variable on the return path to restoring long-run equilibrium after the economy had been disturbed by an exogenous shock.

Now let us suppose that for some reason on other commodity prices rise while the stock of money remains unchanged, or that the stock of money is diminished while prices remain temporatily unchanged. The cash balances will gradually appear to be too small in relation to the new level of prices... I therefore seek to enlarge my balance. This can only be done - neglecting for the present the possibility of borrowing, etc. - through a reduction in my demand for goods and services, or through an increase in the supply of my own commodity . . . or through both together. ${ }^{4}$

The reduction in demand and/or increase in supply will cause commodity prices to fall until they have reached their equilibrium level. Neither Wicksell nor Fisher mentioned the money-interest rates-investment spending channel of monetary influence in their analyses of movements to long-run equilibrium. Both focused on changes in real cash balances without explaining in detail the substitution and wealth processes involved. Although their long-run vs. short-run analyses were similar in many respects, Fisher was probably more noted for his long-run quantity theory views and Wicksell more for his short-run cumulative process.

\section{Keynes}

Like Wicksell and Fisher, Keynes' position on the monetary transmission mechanism was somewhat

"Fisher [25], p. 153.

4Wicksell, [90], pp. 39-40. Wicksell's treatment of the real balance effect is considered superior to Fisher's becatse the former avoided the trap of dichotomizing the determination of relative prices and the absolute price level. See Patinkin [63].

Page 10 ambiguous. Some critics have contended that he found little or no role for either wealth or relative price effects while others have credited Keynes with having advanced a significant role for both.

Keynes' substitution effect, which was a part of a relatively early portfolio choice model, stressed the money-interest rates-investment spending chamel. Did Keynes think changes in the rate of growth of the money supply affected interest rates? There seems to be little doubt that he did. The principal evidence to the contrary may be found in the following passage from The General Theory of Employment Interest and Money:

There is the possibility, for the reasons discussed ibove, that, after the rate of interest has fallen to a certain level, liquidity-preference may become virtually absolute in the sense that almost everyone prefers cash to holding a debt which yields so low a rate of interest. In this event the monetary authority would have lost effective control over the rate of interest. But whilst this limiting case might become practically important in future, I know of no example of it hitherto. Indeed, owing to the unwillingness of most monetary authorities to deal boldly in debts of long term, there has not been much opportunity for a test. Moreover, if such a situation were to arise, it would mean that the public authority itself could borrow through the banking system on an unlimited scale at a nominal [very low] rate of interest.

Note that after raising the possibility that a "liquidity trap" situation could conceivably arise in the future, Keynes immediately disavowed its existence under conditions (the low employment, low interest rate period of the 1930s) in which Keynesian analysis suggested it would likely occur.

Regarding the second part of the money-interest rates-investment channel, there is considerable evidence that Keynes thought investment to be quite responsive to interest rate changes (Leijonhufvud [53], pp. 157-185). However, the interest sensitivity of investment was restricted in the main to fong-term rates, which changed only slowly.

There are a number of wealth effects to be found in The General Theory which relate to either price-induced changes in wealth (changes in wealth associated with changes in the absolute price level) or interest-induced movements in wealth (changes in weath associated with changes in yields). Of the basic price-induced and interest-induced wealth effects, it has been alleged that "Keynes stated both

"Keynes [51], p. 207. Bracketed expression supplied. 
parts of the wealth effect, emphasized their importance, and then let wealth slip through his fingers by his failure to build it into his analysis." (Pesek and Saving [64], p. 21). This criticism is unjustifed to the extent that those parts of Keynes analyses which subsequently enioyed sustained popularity are not necessarily those parts favored by Keynes. For example, the "liquidity trap" was not an intrinsic part of Keynes" analysis (he denied its occurrence); yet it became closely associated with his name as one of his major contributions.

It is easy to see how Keynes' wealth effects were overlooked by those analysts quick to interpret and popularize his basic theory. Keynes brought up the price-induced wealth effect and minimized its significance in the same passage: "It is, therefore, on the effect of a falling wage and price-level on the dem mand for money that those who believe in the selfadjusting quality of the economic system must rest the weight of their argument; though I am not aware that they have done so. If the quantity of money is itself a function of the wage- and price-level [a variant of the real bills doctrine], there is indeed, nothing to hope in this direction."

Keynes endorsed interest-induced wealth effects more vigorously, but made it clear that even these were of secondary importance. As a man well acquainted with the stock market and windfall gains and losses, he thought interest-induced "windfall effects" had only a minor influence on spending habits.

For if a man is enjoying a windfall increment in the value of his capital, it is natural that his motives towards current spending should be strengthened, even though in terms of income his capital is worth no more than before; . . Apart from this, the main conclusion suggested by experience is, I think, that the short period influence of the rate of interest... is secondary and relatively unimportant, except, perhaps, where unusually large changes are in question. ${ }^{7}$

There is, however, sufficient question about Keynes" view of wealth effects, which appear frequently in The General Theory, to spark a continuing debate. ${ }^{8}$ What Keynes actually meant is less significant than his failure to give either monetary-induced substitution or wealth effects a leading part in his attack against orthodox, classical theory. By vacillating on the im-

${ }^{6}$ Keynes [51], p. 206. Bracketed expression supplied.

${ }^{7}$ Keynes [51], p. 94 .

sSee Keynes [51], pp. 92-93, 319. Among the participants in the Keynes wealth effect debate have been Ackley [1], Patinkin [63], Pesek and Saving [64], and Leijonhufvud $[53]$. portance of the two major channels of monetary influence, Keynes in effect was inviting his interpreters to close of the channels completely.

\section{THE RELATVE PRICE RELATON}

The most frequently cited of the relative price relations, money-interest rates-investment, obviously consists of a money-interest rates channel and an interest rates-investment channel. Closure of either of these channels would eliminate a basic route through which money is presumed to affect spending. This route was virtually sealed off by early interpreters of Keynes (among others) and not re-opened for about a quarter of a century.

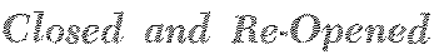

The initial part of the money-interest rates-investment channel was attacked indirectly through innuendo rather than directly either by overpowering theory or evidence. Although Keynes repeatedly stressed the importance of the money-interest rates linkage, J. R. Hicks, the chief architect of the IS-LM "Keynesian" framework, failed to pass along Keynes" emphasis. In Hicks' [44] relatively brief article which became the most popular condensed version of Keynes, Hicks focused on the liquidity trap as one of Keynes' major contributions upsetting neoclassical theory. Nowhere did he indicate that Keynes was unaware of any such situation actually having occurred. The adoption of such slogans as "you can't push on a string," or "you can lead a horse to water, but you can't make him drink" provided popular support for Hicks' interpretation of Keynes' view of the moneyinterest rates channel in periods of economic slack.

Empirical studies of the late 1930 s were the main instrument employed to seal off the interest ratesinvestment channel. Researchers in England and the United States published results of surveys in which businessmen were questioned about the importance of the interest rate in their investment decisions. ${ }^{9} \mathrm{~A}$ vast majority indicated that interest rates had little or no effect on their decisions to invest. These studies were cited prominently by Alvin Hansen [39] in his 1938 American Economic Association presidential address as evidence of the impotence of monetary policy. Moreover, as SamueIson recently noted, ". . . peo-

9See Henderson [42], Meade and Andrews [57, and Ebersole [21], For a humorous criticism of the survey approach, see Eisner [22], pp. 29-40. A more recent example of the survey approach is fotnd in Crockett, Friend, and Shavell [18]. 
ple like Sir John Hicks said that as far as short-term investment is concemed, interest is of no consequence as a cost; and as far as long-term investment is concerned, uncertainty is so great that it completely swamps interest, which leaves you with only a miniscule of intermediate investment that is interest elastic." ${ }^{\prime \prime 0}$

The eventual re-birth of the relative price channel did not occur until well into the $1950 \mathrm{~s}$, although the seeds were planted long before. The emergence of portfolio choice models in the 1950s and 1960s ushered in, among other channels, the old money-interest rates-investment route.

Much of the literature dealing with portfolio choice models has been associated with money demand studies. Portfolio choice theory, however, provides the rationale for the holding of any asset in one's portfolio, including money. Instead of focusing on the individual's or firm's income statement which deals with flows, portfolio choice analysis stresses the stock relationships which are found on the asset and liability sides of the balance sheet. The basic assumptions are that: (1) other things equal, everyone equates the marginal rate of return on each asset in the portfolio allowing for risk (in terms of variance of return and exclusive of price level movements), costs of acquiring information and of conducting transactions; and (2) an increase in the supply of any asset (on a macro level) will lower the price of that asset relative to all others. The increased supply of the asset leads to diminishing marginal returns per unit of the asset, thereby motivating the wealth holder to attempt to substitute or exchange some of the asset whose price has fallen for some of those whose price has not.

Changes in relative prices are a consequence of wealth holders' efforts to restore equilibrium to their portfolio - that is, equate all marginal rates of return. The initial disturbance, a change in the stock of any asset, may produce a chain of substitution effects as wealth holders react to changing asset yields.

Although certain types of money have a zero nominal rate of return by law, money contimues to be held in the portfolio for at least two reasons. First, as opposed to equities, for example (which may carry substantial risk along with a relatively high mean rate of return), money holding is less risky. Second, money economizes on the use of real resources in the gathering of information and in the conduct of transactions. An implication of this latter characteristic is that

\footnotetext{
rosamuelson $[70]$, p. 41.
}

money is held to bridge the gap between income receipts and expenditures. ${ }^{11}$

Which assets, besides money, are included in the portfolio? Much of the controversy surrounding the portfolio choice framework has centered on the answer to this question. The early portfolio choice models greatly limited the range of assets and rates of return. Pigou [65] sketched a rough money-capital model, while Keynes [51] added govemment and private debt to the menu. By assuming perfect substitutability between capital and bonds, Keynes had only the yield differential between money and one other asset (he chose bonds) to explain. Patinkin's model [63] was similar to Keynes" in terms of assets included and yields explained.

A major change in the approach to the number of assets and yields to be examined occurred in the early 1960s. Tobin [77], Brunner and Meltzer [9], and Friedman [28] all expanded the portfolio menu, but in varying degrees.": The differing approaches of these contemporary monetary economists will be examined in some detail.

\section{Thee Wews on the Relative Price Relation}

Tobin ([77], p. 36) suggested that "a minimal program for a theory of the capital account" should include six assets - all of which, except the capital stock, are financial assets - and six yields. The number of assets is only slightly greater than the earlier models, but a substantial step toward reality is taken with the elimination of Keynes' perfect substitutability assumption. The choice of assets is closely restricted to facilitate "purchasing definiteness in results at the risk of errors of aggregation" (Tobin [77], p. 28). If increases in the money supply happen to reduce the supply price of capital - the rate which wealth holders require in order to hold in their portfolios the current capital stock - below its marginal productivity, the capital stock will rise. This is the sole linkage

\footnotetext{
11To pursue further these distinctions would require a detailed analysis of money demand, a project much beyond the scope of this article. The interested reader may wish to consult Pigou [65], Hicks [43], Tobin [77] and BrunnerMeltzer [10]

1.2Cagan [13] aso introduced a sketchy portfolio choice scem nario. More recently, he focused on money-interest rate infuences [14].

The relative price mechanism was also employed by Warburton as eatly as 1946 to explain the tramsmission process. "In practice the effects of a change in demand or in supply, either of a specific commodity or of money (circulating medium, are felt, first in some particular part of the economy and spread from that part to the rest of the economy through the medium of price differentials created at each stage of adjustment." Warburton [88], p. 85.
} 
between the financial and real sectors. The "if" is necessary because the increase in the supply of money which lowers the price of money relative to other assets - may simply result in an increased demand for financial assets, rather than for the capital stock (real assets).

One infers from Tobin that an increase in the stock of any of the financial assets in the macro portfolio is about as likely to stimulate investment expenditures as is money. ${ }^{13}$ In this view it is unelear as to whether an increase in the money stock can lower the supply price of capital directly without setting of a chain of substitution effects ranging all through the spectrum of assets with different shades of risk-retum characteristics. It is apparent from Tobin's comparative static framework, however, that no feedback from the real to the financial sector occurs.

The types of real capital which are affected by portfolio shuffing are delineated closely by BrunnerMeltzer [9], although the number of assets and relevant yields in the macro portfolio are not. They classify three types of capital according to the relation between asset prices and output prices - language somewhat comparable with Tobin's supply price of capital and marginal productivity. ${ }^{14}$

Increases in real capital occur as (not "if") a rise in the stock of base money lowers the relative price of base money and that of its close substitutes, resulting in an increased demand for other assets, those assets being dominated by real capital. "The increase in the price of financial assets simultaneously raises real capital's market value relative to the capital stock's replacement costs and increases the desired stock relative to the actual stock." (Brumner [5], p. 612). Real capital is defined to exclude consumer nondurable goods and services. ${ }^{15}$ Unlike Tobin (with regard to his comparative static models), Brunner and Meltzer ([9], p. 379) view the monetary transmission mechanism as having important feedback effects.

\footnotetext{
13The view that financial or licuid assets other than money $\left(\mathrm{M}_{1}\right)$ can abont as likely affect the real sector, is advocated more strongly by the Radeliffe Committee [17], Gurley and Shaw [37], and Gramley and Chase [35], in what became known as the "New View" (from Tobin [78]).

${ }^{14}$ Friedman's [28] terminology is prices of services and prices of sources as explained in the excerpt from Friedman in the rightmand column of this page. A parallel semantic issue is Tobin's preference for the tern "denutnd debt", Friedman for "high-powered money", and Brumer-Meltzer for "base money".

${ }^{15}$ Brumner added the general thought that "The wealth, income, and relative price effects involved in the whole transmission process also tend to raise demand for rondurable goods." Brunner [5], p. 612 .
}

Friedman [28], in his portfolio choice-relative price analysis, is less formal than either Tobin or BrunnerMeltzer in that he attempts no classification of types of real capital, portfolio assets, or relevant yields. Friedman acknowledges that an increase in the money supply affects the portfolio of the financial sector first, but the subsequent increase in demand may be as likely reflected next in consumer nondurables as in any areas of real capital. Possible scenarios are outlined by Friedman in several places. ${ }^{16}$ Initially, the prices of sources are raised relative to the prices of services, thereby inducing investment and consumer expenditures.

The key feature of this process is that it tends to raise the prices of souces of both producer and consumer services relative to the prices of the servm ices themselves; for example, to raise the prices of houses relative to the rents of dwelling units, of the cost of purchasing a car relative to the cost of renting one. It therefore encourages the production of such sources (this is the stimulus to 'investment' conceived broadly as inchuding a much wider range of items than are ordinarily induded in that term) and, at the same time, the direct acquisition of services rather than of the sounce (this is the stimulus to 'consumption' relative to 'savings'). But these reactions in their tum tend to raise the prices of services relative to the prices of sources, that is, to nndo the initial effects on interest rates [broadly defined]. The final result may be a rise in expenditures in all directions withou any change in interest at all.17

\section{A Companison of Three Views}

The Friedman, Tobin, and Brunner-Meltzer views of the monetary substitution effect are distinguished by a number of points of agreement and disagreement. The three views are coincident in the following: (1) the total response of the financial sector to a change in the money supply occurs before the total response of the real sector; (2) money as a medium of exchange is of less significance than money as an asset with regard to the portfolio choice transmission mechanism; (3) changes in rates of return or yields on real or financial assets are the key elements in the transmission process.

To a large extent, the differences in the three views are due not so much to contradictory theories, but

\footnotetext{
10Friedman [28], Fiedman-Meiselman [33], FriedmanSchwartz [34]. Other attempts at pinning down the operi market purchase-bank reserves-interest rates, etc., channels can be found in Cagan [13], Davis [19], and Ettin [23].

17Friedinan [28], p. 462. Bracketed expression supplied. The latter part of this quote represents one of Friedman's interpretations of the feedback effect.
} 
rather shades of emphasis among similar approaches. Because Tobin insists on a formal separation of the capital account (stocks) from the production and in. come accomt (flows), he is led to highlight different aspects of the portfolio choice process than Friectman and Brunner-Meltzer. ${ }^{18}$

Tobin gives the impression that portfolio choice analysis adds little to the Keynesian (not Keynes') view of money-interest rates-investment. Given a consumption function dependent on income, but not wealth or relative prices, consumption can be affected by monetary actions only after investment via the standard Keynesian multiplier. In his portfolio choice analysis, the potential end result of the shuffling of portfolios is a change in real capital, ${ }^{19}$ feedback ef fects from the real to the financial sector do not fit into Tobin's capital account approach. Tobin specifically draws attention to the insignificance of money's medium of exchange property vis a vis its zero nominal rate of return in his portfolio analysis and generally denigrates money's "uniqueness". Changes in money may set off a chain of portfolio reverberations which results in a change in desired real capital, or it may not.

Friedman's avoidance of formal, structural models which specify any unique monetary transmission process has probably contributed significantly to the charge that monetarists' views of how money works are locked in a "black box".20 Friedman's informal tracing of possible monetary channels stresses the point that consumer spending is as likely to be the real sector component first to respond to monetary actions as is investment spending. Although changes in yields are the key to portfolio adjustments, "These effects can be described as operating on interest rates," if a more cosmopolitan interpretation of 'interest rates' is adopted than the ustal one which refers to a small range of marketable securities" (Friedman [28], p. 462 ).

Bunner-Meltzer tread a path between Tobin and Friedman in their methodological approach to port-

\footnotetext{
1.8'Treatment of the capital account separately from the production and income account of the economy is omly a first step, a simplification to be justified by conventence rather than reakism" (Tobin $[81], p .15$ ). It appears, however, that Tobin's efforts at moving toward greater realism (Tobin [84]) are inhibited by the "Ceneral Equilibritum Approach" (Tobin [81]).

19 In an informal analysis, Tobin added consumer durables to the list of "storable and durable" goods - or real capital influenced in the monetary transmission process. See Tobin [80].

2oFriedman's formal model [30], [31] sheds little light on specific monetary transmission linkages.
}

folio analysis. Like Tobin, they attempt to organize the pattern of response of the real sector to monetary impulses and eventually construct a formal model (Brunner-Meltzer [12]). They also emphasize the significance of real capital in the process with only minor references to such spending components as consumer nondurable goods and services.

Like Friedman, Brunner-Meltzer do not attach "if" considerations to the money-real sector linkage, nor do they stress long substitution chains relating money and other financial assets. Their view is also similar to Friedman's in that they: (1) emphasize financial sector real sector feedbacks; (2) do not denigrate money as an indicator of monetary actions; and (3) stress relative prices, of which yields on securities are only a part. Brunner points out that "Every change in relative prices of assets (that is, durables) with different temporal yield streams involves also a change in suitably defined interest rates." 21

In their money demand theory, Brumer-Meltzer [10] dwell on the medium of exchange property of money, but this property does not appear specifically in their formal model [12] of the transmission mechanism. Relative prices in the 1972 model take the form of asset (including securities) prices and output prices, but no distinction is made between investment and consumer goods prices. Finally, in spite of their criticism of IS LM models which reflect a "Keynesian" approach to the transmission mechanism, they grant that if changes in the stock of govermment debt were presumed to have no effect on wealth, "our model could be pressed into the standard, IS-LM framework" (Brumer-Meltzer [11], p. 953).

In summation, these three approaches to tracing monetary impulses are probably not as different as they at first appear. Once the semantic issues are put aside and the preferences for formal vs. informal models are understood, the Tobin, Brunner-Meltzer, Fiedman approaches to the relative price channels of monetary influence are quite similar. It remains to be resolved, however, if more is to be gained by Tobin's admittedly heroic abstractions from reality, Friedman's apparent presumption that the channels are too complex to be captured in any economic

\footnotetext{
2Brunner [8], p. 27. He adds that "The general role of interest rates does not distinguish therefore between the Keynesian and non-Keynesian positions. The crucial difference occurs in the range of the interest rates recognized to operate in the process. The Keynesian position restricts this range to a narrow class of financial assets, whereas the relative price theory includes interest rates over the whole spectrum of assets and liabilities occurring in balance-sheets of households ard firms" (Brtmner [8], p. 27).
} 
model, or Brunner-Meltzer's approach somewhere between these two in terms of answering the questions of the acadenic fratemity and the genemal public of how money works.

\section{Other Developments in the Relative Price Relation}

Two extensions of the relative price relation which, although out of the mainstream of monetary transmission research, merit elaboration are (1) credit rationing and (2) the overshoot, or feedback, phenomenon. The former involves the allocation of resources by price and nomprice criteria, and the latter is a consequence of the dynamic adjustment of the economy to a monetary shock.

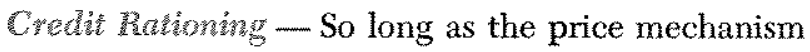
functions in an open market with complete factor and product homogeneity, resources (including credit) are rationed by price. In so-called "imperfect" markets, however, non-price discriminatory practices abound. Among borrowers who are the same in every respect but one, net worth for example, lenders may advance one borrower credit at an $X$ percent rate and another borrower zero credit at any interest rate. At least, that is one implication of the term "credit rationing". As used here, "global" credit rationing is de fined to indicate a reduction in (the rate of) total spending due to a rise in the non-observed interest price of loans.

Traditionally, "local" credit rationing has been associated with the behavior of commercial banks in extending loans in a period of "tight credit". Arguments for commercial bank credit rationing were advanced in 1951 by Robert Roosa [68]. He asserted that in periods of falling security prices (rising interest rates), bankers prefer to pass over relatively more lucrative commercial loans and continue to hold on to their securities in order to avoid a recorded capital loss. Moreover, Roosa contended that banks preferred to hold securities as a means of countering the uncer tainty fostered by the monetary authorities during critical, high-interest rate periods.

Paul Samuelson [69] objected to this analysis on the grounds that it did not conform to the usual tenets of profit-maximizing behavior of the firm. He argued that the usual way of rationing anything in "short supply" was to allow a higher price to do the rationing. Samuelson would not agree that over any other than a very brief period, bankers would hold their assets in relatively low-yielding sectrities, while rationing a set volume of loans at a fixed interest rate.
Subsequently, additional arguments were employed to buttress the credit rationing view, ${ }^{22}$ One of these was that default risk increased relatively more for loans than for securities in tight credit periods. Another was that the banking industry is oligopolistic and is better of to restrict the volume of loans rather than lend out to the point required by the competitive market solttion.

Legal interest ceilings have been invoked more recently in explanations of the working of credit rationing. The basic idea is that a financial institution might be perfectly willing to lend to a borrower at $X$ percent in accord with such criteria as size of loan, default risk, and compensating balance requirements, but if usury or other laws set a ceiling at $Y$ percent which happens to be below $X$ percent, the prospective borrower will not obtain the loan. He may be able to obtain funds from some other source, such as from a lending facility in a state whose celling is higher, or from an effectively unregulated private individual. There are, however, considerable costs of information involved in addition to the higher interest costs which may cause the potential borrower to drop out (that is, be rationed out) of the funds market.

Interest ceilings also affect the flows of funds into financial and nonfinancial institutions. When market interest rates rise above rates payable (considering liquidity, risk, maturity, and tax factors) by savings institutions and state and local govemments, many savers put their funds into less regulated securities markets. The bypassed institutions accordingly cut back their lending activities. Whether the re-channeling of credit results in a reduction of total spending, however, is another matter - one which is rarely treated in the credit rationing literature.

One study, for example, found that Regulation $Q$ ceilings encouraged savers to bypass commercial banks in certain tight credit situations, allegedy forcing commercial banks to curtail credit extensions. ${ }^{23}$ Since bank credit is only one component of total credit, it cannot be assumed that a reduction in total credit or total spending could be attributed to the workings of Regulation Q. According to the author's of the study, the reduction of credit avalable to commercial bank customers "would presumably occur to the benefit of customers of other intermediaries

\footnotetext{
wLindbeck [55], Hodgman [47], and Kane [50] ate among those who have substantially advanced the credit rationing literature.

23 Federal Reserve Regulation $Q$ places a ceiling on interest rates payable by member banks on time and savings accounts.
} 
and/or of those firms able to raise funds directly in the market."2f

If it is presumed that credit rationing at one institution is not offset by increased loan activity elsewhere, then "global" credit rationing, which is accompanied by a slowing in the rate of total spending, occurs. Because all observed interest rates do not necessarily capture a rise in the relative price of credit as represented by greater information and transactions costs (which are assumed to include such costs as increased compensating balances), interest rate changes alone would not give a complete picture of the effectiveness of monetary actions. In certain tight credit situations, interest rates rise to slow down spending. But after some point at which interest yields are confronted by legal rate ceilings, interest rates would not give a correct picture of the true cost of credit. An important implication of this analysis is that interest rates likely emit inconsistent signals with respect to monetary influences on spending via relative price changes.

Overshoot Effect - The "overshoot effect" is analogous to the previously-mentioned feedback effect, in which the real sector reacts back upon the financial sector, with the original disturbance having come from the financial sector. Although the overshoot may occur by way of relative price or wealth influences, the vast majority of the literature on this topic is couched in a relative price framework. The term "overshoot" is indicative of the tendency of the initial adjustment of such economic variables as interest rates and income to exceed the steady-state levels. Friedman is often identified as the current leading advocate of this thesis, but the argument has its roots in studies by Fisher, Wicksell, Keynes, and Tooke. ${ }^{25}$

Friedman [28], [29], [33] pointed out in several places that changes in the money supply and interest rates are inversely related for only a short period. A rise in the money supply, for example, is associated with a fall in interest rates initially. After some period of time, the fall in interest rates will have stimulated spending and the demand for credit. The rise in the

\footnotetext{
$\because+J a f e e$ and Modigliani [49], pp. 871-72. Athough Jaflee and Modigliani suggest that credit rationing of commercial banks is offset by increased loan activity in other areas, the reverse does not necessarily hold. The FRB-MIT model, with which Modigliani has been closely associated, finds a credit rationing effect through non-commercial bank savings institutions not of set by increased commercial bank activity. See deteetw and Gramich [20].

25See Fisher [25], Wicksell [89] (natural interest rate vs. marcet interest rate), Keynes [5]] (the Gibson paradox), and Tooke [86] (the Ricardo-Tooke Conundrum).
}

demand for credit will tend to reverse the initial fall in interest rates. If spending is continually stimulated, demand pressures will force up the price level and price anticipations which, in turn, add upward pressures to interest yields.

The extent to which interest rates overshoot their equilibrium value is dependent on many factors, including initial conditions and the duration and degree of monetary stimulus. It should be noted that the rise in the price level lowers the real value of monetary assets. At the higher price level, the quantity of money demanded is less in real terms. Also, the rate of increase of the money supply tends to slow automatically due to "feedback effects through the monetary mechanism" (Friedman and Schwartz [34], p. 562). Thus, prices, interest rates, money, and general economic activity are all subject to the overshoot phenomenon.

Similar dynamic analysis has been offered by Brunner-Meltzer. Through changes in wealth and relative prices, they postulate that monetary impulses alter the magnitude of and rate of return on the capital stock. "Variations in the stock of real capital, of income expected from human wealth, or the yield expected from real capital affect the allocation pattern of financial assets, trigger the interest mechanism, and generate a feedback to the asset prices of real capital." Thus, "monetary impulses not only affect the real processes but real impulses feed back to financial processes." 26 Brunner atso noted the role of price anticipations in the feedback process and postulated that without continuing money growth acceleration, initial output and employment gains would be offset over time. ${ }^{27}$

Tobin's basic comparative static framework revealed no role for the overshoot effect. On at least two occasions (Tobin [82], [841), however, he engaged in dynamic analysis. On both occasions he pointed out that initial disturbances in the real sector which affect the money supply (endogenity of money) are a plausible explanation of observed money-income relationships. In one instance (Tobin and Brainard [84], p. 119), he noted that an exogenous change in bank reserves would produce an adjustment path of the yield on real capital which overshoots and oscillates.

\footnotetext{
2 Brumer-Meltzer [9], p. 379

-rBruner [7], p. 13. Friedman ([29], p. 10) made the same point regarding monetary acceleration via a comparison of the market unemployment rate-natural memploynent rate with the market interest ratematural interest rate.

The feedback effects noted in the fornal Brunner-Melzer modes [12] are started by an initial disturbance in the otatput narket, and thes are not quite comparable to eartier analysis.
} 
Even the standard IS-LM framework can be altered so as to give interest rate and income overshoots. ${ }^{28}$ It can be shown that differences in the adjustment pattern of investment to interest rates and money demand to interest rates are capable of producing interest rate and income overshoots. If investment is dependent at all on the current interest rate, a sharp drop in interest rates can cause investment to expand and income to rise; if money demand is a function of income, there ensues a rise in money demand which reacts back on interest rates.

It is possible to conjecture fairly complicated reaction patterns to relative price changes, even without such complications as an accelerator effect, or changes in the absolute price level. Even working within a simple analytical framework, it would be difficult for policymakers to attempt to stabilize incomes or interest rates if they did not know whether the adjustment paths were monotonic or cyclical. Considerable empirical verification of the overshoot or cyclical process in the "real" economy has been provided."

\section{THE WEALTH RELATON}

The monetary channel of influence which operates through changes in wealth is best approached by examination of the linkages between wealth and consumption. Although the substitution effect, in some versions, is seen to work through consumer spending as well as investment, the wealth effect has been typically limited to the consumer sector. One definition of nonhuman money wealth is

$$
W_{\mathrm{NH}}=\mathrm{PK}+\mathrm{D}+\frac{\mathrm{G}}{\xi}
$$

where

$$
\begin{aligned}
\mathrm{P}= & \text { price of real capital } \\
\mathrm{K}= & \text { stock of capital ( } \mathrm{PK}=\text { market value of equity) } \\
\mathrm{D}= & \text { monetary base plus traction of bank debt not } \\
& \text { counted in } \mathrm{PK} \\
\mathrm{G}= & \text { government debt (one dollar multiplied by the } \\
& \text { number of securities outstanding, each of which } \\
& \text { is assumed to be a consol) } \\
\mathrm{r}= & \text { market interest rate }\left(\frac{\mathrm{G}}{x}=\right.\text { matket value of out- } \\
& \text { standing debt). }
\end{aligned}
$$

Monetary factors affect each of these components of nonhuman money wealth in varying degrees.

\footnotetext{
-sSee Laidler [52], Smith [73], Tanner [74], and Tucker [87].

ansee Silber [72] and Christ's ([16], pp, 444-45) review of large econometric models.
}

Real human wealth, $w_{H}$, is determined by the present value of one's expected lifetime income, a concept related to permanent income or even disposable income (with the appropriate lags), but not directly related to monetary actions. Real consumption (c) is assumed to be a function of both types of wealth as described by

$$
\mathrm{c}=\mathrm{c}\left(\mathrm{w}_{\mathrm{H}}, \frac{\mathrm{W}_{\mathrm{NH}}}{\mathrm{p}}\right) \text {. }
$$

The human wealth concept forms the typical Keynesian element in the consumption function. The relation between nonhman wealth (divided by the price level), and consumption is probably less well accepted.

Because the arguments for the $D$ and $\frac{G}{r}$ elements of the wealth effect are closely intertwined, they will be discussed together as "Real Balance Effects". The PK section follows under the heading "Equity Effects".

\section{Real Balance Effects}

As mentioned earlier, Keynes discussed several different real balance effects, but made little use of them in his general framework. Ironically, it was the work of a prominent Keynesian interpreter which sparked renewed interest in real cash balances. Pigou, who generally receives the lion's share of the credit for reviving real cash balances, ${ }^{30}$ was disturbed by Alvin Hansen's stagnation thesis.

Hansen [40] charged that even with flexible prices and wages, a perpetual state of less than full employment could well be the natural resting place for the economy. Such neoclassical economists as Pigou were willing to concede that an assumption of inflexible prices and wages could be consistent with the thesis of a less than full employment state, but only given this important assumption. Pigou demonstrated that the rise in real cash balances associated with a falling price level and unchanged money stock would increase consumer spending, reduce saving, and thereby permit the rate of interest to rise above some assumed "liquidity trap" level.

By associating consumption with real cash balances, Pigou drove a wedge into the small opening left for monetary policy by the Keynesians of the late 1930s. Because consumption comprises a much larger percentage of total spending than business fixed invest-

30Pigou [66]. See also Haberler [38] and Scitovszy [71]. 
ment, the potential for monetary policy to affect total spending was greatly expanded. Pigou and others who formulated real cash balance theories in the early 1940s did not claim much empirical significance for this effect. Their concem was only to show that it was theoretically plausible for the economy to return to full employment under the assumption of price and wage Hexibility. They did not take up Keynes' windfall effect or any other aspect of the monetary wealth effect. Thus, their concern was limited to the " $\mathrm{D}$ " portion of the nonhuman wealth definition, with the relevant debt typically taken to be the govermment's demand debt (or monetary base).

Don Patinkin took up the discussion of real cash balances in the post-war period. ${ }^{31} \mathrm{He}$ also ignored the interest-induced wealth effects and focused on theoretical rather than empirical considerations. Patinkin's chief contribution to the channels of influence controversy was to spell out the interplay between the positive real cash balance effect and the negative real cash balance effect which combine to produce proportionality between money and prices (the "quantity theory") between periods of short-run equilibrium. ${ }^{32}$

Prominent among those disputing the usefulness of the real cash balance approach have been Hicks and Hansen, who also downgraded the monetary relative price channel. Hansen's [41] criticism of the real balance effect was limited to a short note in which he agreed that the effect could theoretically bring a halt to a downtum, but could not generate the spending required to attain full employment.

Hicks devoted more effort to wealth considerations, as demonstrated by the important role of wealth in his landmark book, Value and Capital [45]. However, neither in Value and Capital nor subsequently did he attach much significance to a monetary wealth effect. Hicks omitted real balance effects in Value and Capital and only thirty years later did he find any use for the concept at all. ${ }^{33}$ The dominant chamnel of mone-

\footnotetext{
31Patinkin [63]. Patinkin's first articles on real cash balances appeared in the late 1940s.

32The positive real balance effect associates the demand for real balances (positively) with money and the negative real balance effect associates the demand for real balances (inversely) with prices. The demand for goods is related to one's holding of real cash balances.

3s Leijonhufvat noted Hicks lack of consicteration for either price-induced or interest-induced wealth effects in Value and Capital. "It is interesting to note that the first edition of Value and Capital did not take the real balance effect into accomat. In the second edition, Hicks responded to the criticisms of Lange and Mosak on that issue by admitting: 'I was too much in love with the simplification which comes from assuming that income-effects [Pigon effects] cancel out when they appear on both sides of the market' (p. 334).
}

tary influence, so long as no liquidity trap exists, was through his portfolio choice-relative price route.

Exactly what should be included in the "D" portion of the real balance wealth definition has been the subject of debate in more recent years. In most cases, private debt typically is assumed to cancel out. However, Pesek and Saving [64] maintained that becatse no interest is paid for demand deposits, wealth (which accrues to bank stockholders) increases in proportion to demand deposits. Thus, they would count both inside money (demand deposits) and outside money (monetary base) in net private wealth, contrary to the traditional view which counts only outside money. To include all inside money as wealth, however, would likely result in some double counting.

If the inside money benefits to banks are capitalized in the value of the banks' stock, as are the typical gains to nonbank firms, the same inside money would be found in the "D" portion and the "PK" portion of the wealth equation. To the extent that demand deposit gains are not capitalized instantaneously, there should be some allowance made for the addition of inside money to net wealth. The effect on spending would be through additional outlays by bank stockholders.

What about government securities $(\mathrm{G})$ held by the public? Do these represent private wealth? They only represent private wealth to the extent that the public does not anticipate offsetting future tax increases to eliminate such debt. The $\frac{G}{1}$ term in the wealth equation may have some effect on spending through: (1) changes in the magnitude of $\mathrm{G}$; (2) changes in the composition of $\mathrm{G}$; and (3) changes in $r$.

One source of controversy concerning changes in wealth has been the relation between $G$ and $D$. The two have frequently been summed (interest-bearing debt plus non-interest bearing debt) in empirical and theoretical investigations of the effects of "liquidity" on the economy. If it can be assumed that $G$ and $D$ are good substitutes, their composition is of less con-

While this did not lead him to reconsider also the assumption that the wealth effects of interest changes cancel, it may well be that the same remark applies also to this problem." (Leijonhufvud [53], p. 275).

Hicks eventually took note of the real cash balance version of the wealth effect in a review of the first edition of Patinkin's book. Hicks missed the point initially that a rise in real cash balances stmulates spending, as he later atmitted in his Critical Essays ([46], p. 52). In 1967 he recognized the existence of a 'liquidity pressure effect - but thought it had merit only in restraining an expanding econony. This concept, of course, is a variation on the monetary policy "can't push on a string" thesis.

Page 18 
cern than their sum. ${ }^{3+}$ Early empirical investigations of wealth effects published shortly after the accumulation of muck government debt in World War II often tested the real balance effect as the sum of $\mathrm{G}$ and D.3: Many found a strong relation between liquid weath and consumption. If this can be called a direct channel, a more indirect route, via interest rates, has been envisioned by others.

Tobin 4 79] emphasized aggregate monetary wealth and its composition with respect to the effect on interest rates. Not only does an increase in monetary wealth relative to real assets lower the supply price of capital and thereby induce investment, but an increase in short-term government debt relative to longterm debt (no change in aggregate debt) may achieve the same result. These actions are closer to fiscal policy or debt management policy than to what is normally labeled monetary policy.

To the extent that monetary actions affect the yields on government debt, there is an interest-induced monetary wealth effect on consumption. If expansive monetary actions lower the "r" component of G $\frac{G}{r}$ proportionately more than ${ }^{\text {" }} G$ " in the wealth definition, nonhuman money weatth rises, as does (under typical assumptions) consumption. Ot course, a monetary overshoot effect would reverse the fall in interest rates and subsequently work in the opposite cirection on consumer expenditures. Also, if the rise in the price of securities (fall in interest rates), induces those wealth holders who have not yet purchased securities to pay a higher price for their securities, this particular group may curtail their outlays for consumer goods. ${ }^{30}$

"4Proponents of the "Now View" also add non-govemment, non-bank liabilities, such as savings and loan shares, to the total. See Brunner $[6 \overline{\text {. }}$.

The Radclife Committee [17] found a role for money to aftect spending if it added to total liquidity, to include funds made avalable by non-bank financial institutions. Iohm Gurley noted that the Committee "believes that changes in these [interest] rates have had little direct effect on spending; and it does not think that there is any direct, close connecton between the money supply and spending. But while money is shoved out of the house through the front door, for all to see, it does make its reappearance surreptitiously through the back door as a part of general iquidity: and the ronost important sonrce of liquidity is the large group of financial institutions." Gurley [36], p. 685 Bracketed expression supplied.

35See Patinkin's empitical chapter [63]. Lemer [54] theorized that continued growth of govermment debt, as in World War II, would eventually induce sufficient consumer expenditures as to eliminate any excess of savings over investment at full-employment income. He fid not attempt an empitical test, however.

stisee Leijonhufvud (553], pp. 241-42) for a discussion of this effect. Lawrence Klein, who recognized the potential of interest-induced changes in wealth to affect consumption
As far as the real-balance effect, especially that part which pertains to " $D$ " is concerned, there is little indication that Tobin, Brumner-Meltzer, or Friedman envision monetary influences as having much impact through this channel. ${ }^{87}$ In at least two cases, however, these leading monetary economists have found a strong role for the moneymequity channel. Their views on the money-equity route will be discussed after mention of some of the earlier proponents of this channel.

\section{Equahy wed}

How can monetary actions affect the market value of equity, "PK"? One answer was provided by Lloyd Metzler, who re-opened the equity chamel in 1951 which had been described earlier by Keynes. Metzler [58] was probably the first economist whose formal model included the investment-borrowing costs channel and both aspects of the wealth channel - real cash balances and private equities. ${ }^{38}$ Metzler, however, made the unusual assumption that the Federal Reserve increases the money stock through purchases of privately held common stock.

An increase in the money stock (in the Metzler model), given full employment, results in a proportional increase in prices and thus no change in consumption with real balmees remaining constant. The Federal Reserve's purchase of common stock lowers net private wealth (the volume of securities in private hands falls) and consequently, consumer spending. The fall in consumer expenditures is accompanied by a rise in saving, a fall in the rate of interest, and the consequent increase in capital intensity. Criticism of Metzler's model centered on his unusual assumptions, which, among other results, gave a negative association between monetary growth and consumer spending.

The more orthodox conjecture, that monetary growth, the market valuation of equities, and con-

inversely, related to the author recently that an inverse relation is more likely in the depression state, such as the 1930s, than today.

37"Like Friedman (1970, pp. 206-7) we believe that the real-balance effect is one of several explanations of long-run changes in the IS curve. We agree, also, that the short-run importance of the real-balance effect is small enough to neglect in most developed economies where real balances are a small part of wealth. In our analysis the size of the traditional real-balance effect depends on the proportion of money to total nonhuman wealth, a factor that is less than .05 for the United States" (Brumer and Meltzer [11], p. 847 ).

38Timbergen provided the first empirical test of an equitiesconsumption relation. Dividing consumption into that by income eamers and non-workers, he foend that "a fall in capital gains had already caused a decline in consumption between 1928 and $1929^{\circ}$ (Tinbergen [75], p. 78). 
sumer spending are all positively related, has been given theoretical and empirical support by Franco Modigliani. Modigliani [59], [60] advanced formal theoretical models in 1944 and 1963. He recognized a role for wealth-consumption influences in his revised model of the economy (called the "mid-50s" model) which he acknowledged had been omitted from the 1944 model. His new consumption equation was

where

$$
\mathrm{C}=\mathrm{C}\left(\mathrm{X}, \frac{\mathrm{NW}}{\mathrm{p}}, \mathrm{r},\left[\frac{\mathrm{V}_{\mathrm{o}}}{\mathrm{p}}\right]\right)
$$

$$
\begin{aligned}
X & =\text { real income } \\
\frac{N W}{p}= & \text { Modiglianits life-cycle aggregate labor income } \\
& \text { variable } e^{39} \\
r & =\text { the rate of return on (or cost of) capital } \\
\frac{V_{0}}{p}= & \text { the net worth of the private sector. }
\end{aligned}
$$

The two latter monetary-related terms, the borrowing cost variable and the wealth variable, appeared in much the same form in the FRB-MIT model of the later 1960 s, a model with which Modigliani has been closely identified.

The money-equities-consumption channel in the FRB-MIT model hinges on the substitutability of bonds and stocks. If an increase in demand for, say, Treasury securities, by the Federal Reserve results in lower yields and higher prices for these securities, other investors could well be discouraged from purchasing the now higher-priced Treasury securities, but securities whose price was not initially affected by the Federal Reserve action. To the extent that demand is shifted to equities from Treasury securities because of their higher price, there is a rise in common stock prices, which is reflected in a rise in PK.

The higher equity prices represent capital gains to equity owners. The wealth effect portion of this process is the inducement to spend on the part of equity owners because of their increased net worth. Over a sixteen-quarter period, the equity chamel represents 45 percent of the entire monetary influence on total spending in the FRB-MIT model. ${ }^{40}$

39 Modigliani-Brumberg [62] in 1954 related consumption to one's expected income over his life span. The discounted value of "permanent" income is human weath, or $\frac{\mathrm{Y}}{\mathrm{r}}=\mathrm{W}$. Neither Modigliani-Brumberg nor Friedman [27] related monetary-induced nonhuman wealth to consumption at this early stage.

todeLeem and Gramlich [20], p. 487. Other simulations by Modigliani of the FRB-MIT model indicate an even stronger equities effect when altemate forms of the money-equitiesconsumption equations are ren. Modigliani [61], however, did not accept these as realistic.
It is not likely that Friedman would credit any sort of monetary-induced nonhuman wealth effect as having that much influence on spending. The relative price channel dominates his discussion of the channels of monetary infuence in numerous articles (Fiedman [28], [33], [34]), In more recent studies in which Friedman developed a formal economic model, he omitted wealth from the consumption function, using only $\mathrm{C} / \mathrm{p}=\mathrm{f}\left(\frac{\mathrm{Y}}{\mathrm{p}}, \mathrm{r}\right) .^{41}$ One indication that nonhuman wealth is of some significance in his view of the transmission process emerged in a recent article in which he attempted to delineate initial and subsequent shifts in the IS-LM apparatus. ${ }^{42}$

Until recently, Tobin apparently shared Friedman's lack of enthusiasm for monetary-induced wealth effects on consumption. His omission of wealth influences on consumption may be found in his informal models of the early 1960 s as well as his more detailed models of the late 1960s. ${ }^{43}$ It is not so much that Tobin denied a wealth effect, rather that he preferred to keep stock and flow variables separate. Thus, consumption (and saving) were functions of flow variables - specifically income - and not wealth, a stock concept. "The propensity to consume may depend upon interest rates, but it does not depend directly on the existing mix of asset supplies or on the rates at which these supplies are growing."

In a significant departure from most of his previous studies, Tobin [85] stressed the importance of wealth effects in an article co-authored with Dolde in 1971. They considered the "two major recognized channels of monetary influence on consumption: (A) changes in wealth and in interest rates, (B) changes in liquidity constraints." $4 \bar{\nu}$ They recognized the historical sig-

41Fiedman recognized the inadequacy of the above consumption function ([30], p. 223) and ([31], p. 331) "in a full statement" (1301, p. 223), because it exchided wealth, but he stated he was attempting to stick to Keynesian short-period analysis. In a much earlier study, Friedman $[26]$ endorsed the real balance effect more vigorously.

f-Fiedman ([32], p. 916) discussed shifts in IS-LM curves (first round effects vs. subsequent effects in a manner consistent with the view that wealth influences subsequent shifts. Friedman did not mention "wealth" but BlinderSolow [2] interpreted his discussion in that context.

4:SSee Tobin's early models [77], [78] and later models [81], [841. He did mention monetary influences on saving/ consumption in "Money, Capital, and Other Stores of Value" [77], and gave the relation somewhat more prominence in the earlier "Relative Income, Absolute Income, and Saving" [76].

4t.Tobin [81], p. 16 .

45Thin Dolde [85], p. 100. Tobin's comments concerning the volatility of the marginal propensity to consume, espem cially with respect to the 1968 tax surcharge, provide a 
nificance of the Pigon effect, but weath changes in their study were associated with capital gains (equity effect). Their liquidity effect referred to the cost of converting nonliquid assets to liquid form in a world of imperfect capital markets. The level of the penalty rate of interest (a relative price) inhibits or encour ages conversion of nonliquid to liquid assets.

Using a Modigliani-Brumberg life-cycle model, they concluded that wealth (equity values), interest rates, and the liqudity constraint all have important influences on consumer spending. Their model was basically a reduced form, in that they did not provide the linkages between monetary policy actions and monetary effects.

Brunner and Meltzer have long incladed a prominent role for wealth effects in their view of the monetary transmission process. "PK" is the component of nonhuman wealth mentioned most favorably in their analysis. For example, in discussing the chain of events following an injection of base money, Brumer Meltzer noted that "the resulting rise in the market value of the public's (nonhuman) wealth raises the desired stock of capital III and the desired rate of real consumption." "They further stated that relative price effects also operate to increase real consumption following the expansive monetary action.

At a later cate Brumer again stressed the importance of "PK" relative to the real balance effect in the transmission process. "The dominant portion of the wealth adjustment induced by a monetary impulse occurs beyond a real balance effect and depends on the relative price change of existing real capital. The monetarist analysis of the transmission mechanism determines that this portion of the total wealth effect thoroughly swamps the real balance or even the financial asset effects. ${ }^{* 4}$

Real balances are included, however, in Brunner and Meltzer's [12] formal model. Total spending

clue as to why he chose to include wealth in the consumption function." "Now if it had been true that the incomefow theory of consumption was a resounding stecess, and that its indications were bejng bome out all the lime, then we wouldn't need to go into the wealth theory or the lifecycle theory and all that. We woulcin't need to seek a fundamental theory about why savings ratios are what they are and how they relate to varous parameters. But we all know that the cash income theory is not a resoming success," Tobin [83], p. 150 .

46 Bronate and Meltzer [9], p. 377. Capital III refers primarily to certain types of consumer durable goods. Examples of the other wo types of capital delineated by Brunner and Meltzer are machinery and equipment (Type I) and houses (Type II)

4 Bfunner [7], p. 5 . (which includes consumer spending) in that model is influenced by, among other factors, nonhuman wealth. Their nonhuman weath variables include real capital, the monetary base, the stock of government debt, and the value of commercial banks' monopoly position excluded from real capital (Pesek and Saving effect).

Formal economic models now routinely include wealth and/or substitution effects on consumption. ${ }^{48}$ Few, if any, of the empirically-oriented, structural models permit all the wealth effects on consumption described above. For example, the FRB-MIT model (Board of Governors [3]) has an equities effect but no real balance effect; the Wharton Mark III model (McCarthy [56]) has a real balance effect but no equities effect. Only when model builders make allowance for all possible monetary effects are so-called structurally rich models as likely to reflect as significant a money-spending impact as reduced form models. There is, of course, a good possibility that yet undiscovered wealth, relative price, and even monetary income effects will be found in the monetary channels of the future.

\section{SUMAAY}

This article surveyed the relative price and wealth changes set in motion when the quantity of money supplied changes relative to money demanded. Relative price and wealth changes were viewed as major elements of the monetary transmission mechanism around the turn of the century (in rudimentary fashion) and in recent years, but in much of the intervening period their role was subjected to considerable question.

Fisher and Wicksell favored one approach in which wealth was the dominant monetary force and another in which relative prices were of more significance. Keynes amplified both views, but his major interpreters were not so inclined. It is, in fact, ironic that J. R. Hicks, who formulated the IS-LM interpretation of Keynes, downgraded both monetary wealth and relative price infuences, despite his pioneering research into basic wealth [45] and portfolio choice fields [43].

Real balance wealth effects were revived by Pigou, Patinkin, and others while Metzler re-formulated the equity wealth effect. Tobin, Brmner-Meltzer, and Friedman advanced the portfolio choice-relative price effect in the early $1960 \mathrm{~s}$, and with the exception of

4see, for example, Christ 15] and Rasche [67]. 


\section{EXAMPIES OF HOW MONEY WORKS}

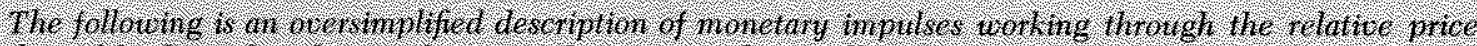
and wealth channets. The numbers are dhosen enively for illustrative pumposes and bear no relation to curren ictrat mognitudes. This hypothesized scenaro tepresents sone of the possible ways in which spending might respond to a nonefary injection. To begin, assitme a bale of government bonds by the Treasiry to bond dealers. Whe bonds being sthisequemily purchasid by the federal Rescrve.

\section{Relative Price Chamnel}

The purehase of govermment debt by the Hederal Reserve (Fed) increases bank reserves and lowers the vield (raises the price) on Treastnr, securities: The banks lend ont (rncrease denand deposits) some mil tiple of the higher level of reserves by lowering bank loan rates, the higher price of Treasury secmities en: courages investors to purchase securities whose prees have not yet wisen.

At this point the nomey smply thas nisen and interest rates lave dechined Borrowers obtained noney balances in orker to purehase reat assets (tars, houses, nachinery) and/or finincial assets (stocks, bonds). depending on the current and expected relative prices of the assets, if real assets ate purchased through either consumer or investnent expendiares, the price of existing real capital nses, II fmancial assets are pur. chased the price of existing real capitil rises tha eapitalization of the assels. The nise in the price of existing reat copital encomrages the protuction of ad ditional eapital. Observed dedines in interest rates also represent fower borrowing costs, an additional stinulins to the production of goots and services. The lower costs nay be interpreted as a fall in the rental price for the senvices rendered by an asset. Moreover. a fall in interest rates conld elmminate the effects of credif rationing, which are presumed to trecti at high levels of interest rates:

In other terms, if $160 \mathrm{th}$ comamption $(c)$ and investnent $(1)$ depend on hiterest rates $(r)$ and the price of existing real eapital (P) relative to the price level

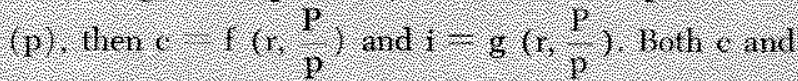
3 are stimulated if a falls from. say 004 to 02 and rises rrom 1 to 2

As the noney supply rises, havever, and new re epients of money bitances hire more workers, buy more equipment, pay out larger elividends, or pay ligher wages, the price level legins to rise. The closer the economy is to capacty operations, the more rapid the increase in the price level Moreverer demand for credit expands, and this together with the price level rise puts upward pressure on market interest rates. The result may be a retum of the interest rate and price vanables to their earter relations. that is: $t \cdot r\left(04, \frac{2}{2}\right)$ and $\log \left(04: \frac{2}{2}\right)$

\section{Wealth Chamel}

The isstance of geverment tebt by the Treasury results in a transfer of assets from transactor A (who parrehised the debi) to transactor B (paid by the govermment with the proceeds from A). A holds an asset, niterest and principal on which can be paid of by the goverminent through, anoung other means, an increase in taxes. To the extent that the public does not anticipate the goverminent raising taxes fo pay of its onlstanding debt. govennent debt represents wealth to the private sector. Whether taxes are anticpated or not the falue of a unit of coverminent debt falls with the itse in niterest intes cansed by the isstanice of new tebt

Tederal liesenve purchase of goverminnt debt. howevor, mambiguously increases wealth becanse the Ted camot caise taxes, and its purchase of government tebt mitilly lowets interest rates. In

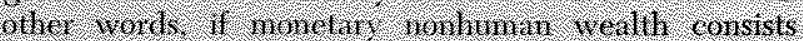
of bitside money (D), governinent londs (G) di: vided by the market tate of inferest $(I)$, and the birec of capital IP times the capial stod (K). then

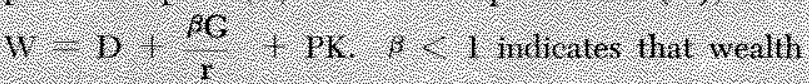

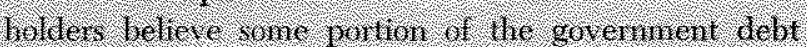
Will be paid of by increased fruture texes. Real nomhnim weallh, w, is obtamed $b$ y deffating the abore by the pirice level, $\mathrm{p}$ or $\mathrm{W}=\frac{\mathrm{D}}{\mathrm{D}}+\frac{\mathrm{gG}}{\mathrm{pr}}+\frac{\mathrm{PK}}{\mathrm{D}}$ Given inital Whives of $\mathrm{D}=100, \mathrm{G}=200 . \mathrm{k}-10,000, \mathrm{~s}=04, \beta=$ $5, p, 1$ and I -1 , then w $\frac{100}{1}+\frac{(5)(200)}{1(04)}+$ $1(10,000)$, and therefore, $w=100+2500+10,000$. It is assuned that $e=c(w)$ where $e, \beta$ or that is, wealti postively influences consumption expenditures.

Issuance of new goverment debt by the Treasury of 5 bonds is assumed to raise interest rates to 041. Such that this component of wealth remains unethanged. $\frac{8 G}{\mathrm{pr}}-\frac{5(205)}{1(041)}=2500$. if the Fed pur chases the govermment debt however, the change in the first two wealth components is. $\frac{\mathrm{D}}{\mathrm{D}}+\frac{\rho \mathrm{G}}{\mathrm{pr}}$ $\frac{105}{1}+5(200)=105+2500$

A number of other wealth effeets nay be distin: guished, some of which are not retated to a fed purchase of Treasury debt:

1) The Pigou effeet nomally associates a fall in the price level with a constant level of D. Example: 


\section{Wealth Channel teont:}

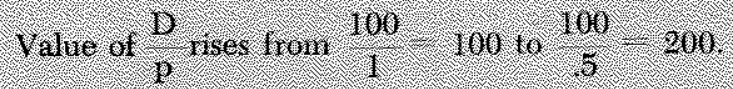

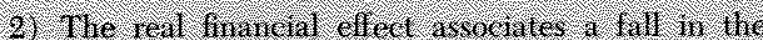



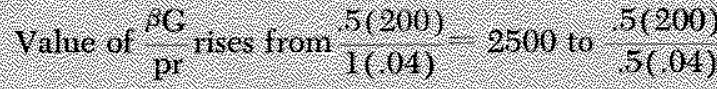

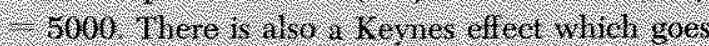

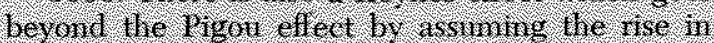
real eash balantes lowers hthest hates anl stm ilates invest trent

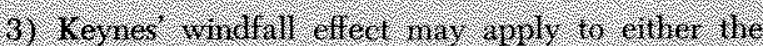
governineat bonds or the capilal stagk vorion of ronilimin weallh

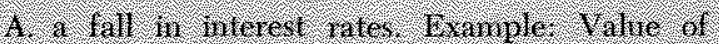

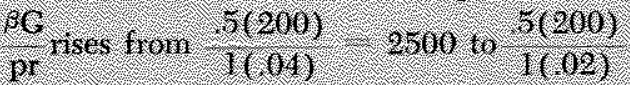
70100.

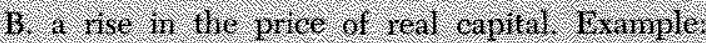

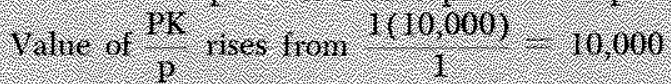
10.2110001 . 20,0001

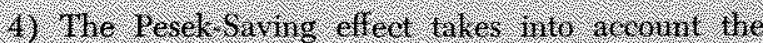

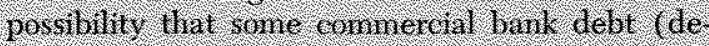

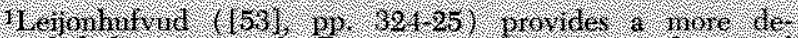

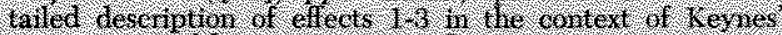

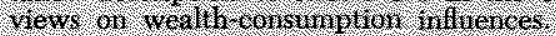

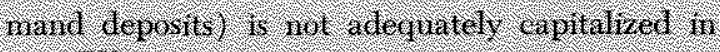

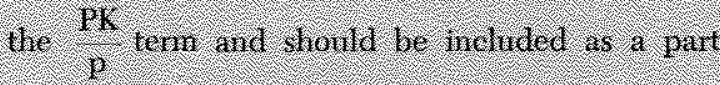

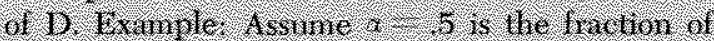

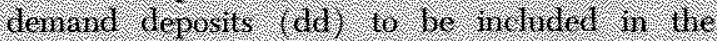

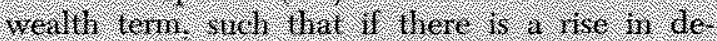

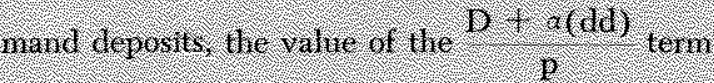

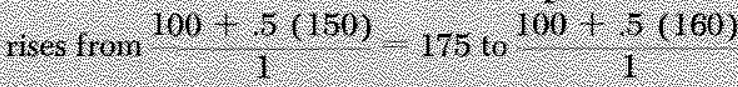
160

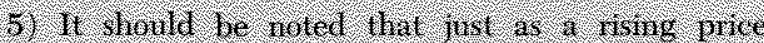
level tends to oftset tho inithly expansme of feats of nonetar actions hroming he relative

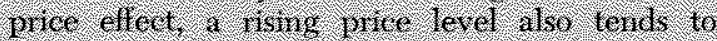

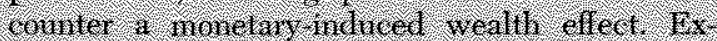

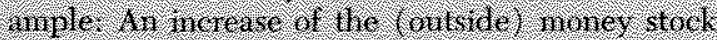
(1) witrall incteased the wine of ronhingh

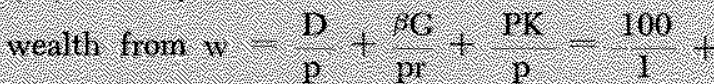

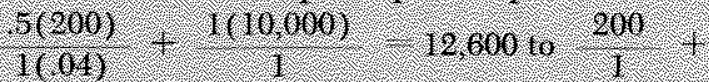
$5(200), 2(10) 000)$

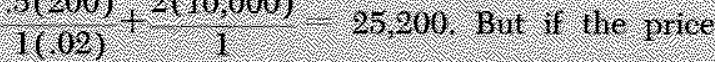

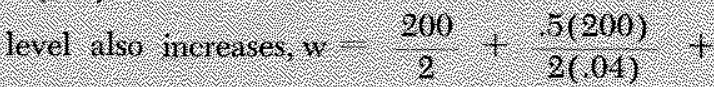

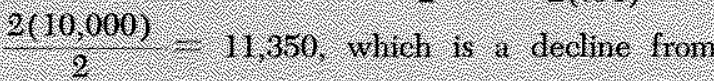

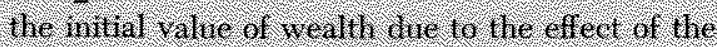

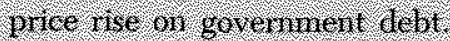

Friedman, have also highlighted the equity wealth effect.

These hardly exhaust all the ways in which monetary impulses affect spending. For example, an income effect occurs when the Treasury draws down its bank balances to purchase goods and services. A decline in Treasury deposits relative to demand deposits increases the money supply (other things equal) and income.

Alternatively, a rise in the money supply may be associated with a change in relative prices and no change in wealth. For example, a fall in currency relative to demand deposits increases the money supply and lowers bank loan rates, but there is no rise in real balances - if defined only as outside money - and no change in Government debt.

Thus, depending on how the money supply is caused to change relative to money demand, some effects on spending are set in motion, but not necessarily all. Moreover, the fact that initial conditions, to include all relative prices, are never the same suggests that under one set of circumstances initial monetary effects may be on, say, consumer durable goods expenditures, and under another set, state and local government purchases. To follow explicitly the channels of monetary influence whenever there occurs a change in the quantity of money supplied relative to the quantity demanded, one would have to know as a minimum the cause of the change in the money supply, all relevant relative prices, and the impact of other exogenous events on spending units. Add to this the effect of feedback forces, both relative price and wealth, and it becomes less surprising that the contents of the monetary black box have been difficult to unravel.

The complexity of the forces at work, however, does not mean that one should despair of forecasting the effect of monetary influences on total spending and rely on (presumably) more elementary tools to guide economic activity. The effects of other policy actions are also difficult to trace with certainty. ${ }^{49}$

\footnotetext{
4"It has become clear in recent years that simply forecasting the result of fiscal policy effects on total spending requires more than reliance on some variation of the deceptively simple relations $\mathrm{Y}=\mathrm{C}+\mathrm{I}+\mathrm{G}$ and $\mathrm{C}=\mathrm{C}(\mathrm{Y}-\mathrm{T})$. These
} 
The likelihood is that all possible channels of monetary or other policy actions have not been spelled out completely in any one model. There remains much room for research which would narrow the gap between economic reality and economic models.

relations imply a direct link between govemment spending $(G)$ and total spending ( $Y$ ), and between disposable income $(\mathrm{Y}-\mathrm{T})$, which includes tax changes, and consump- tion (C). What does not appear in these smple relations are the vector of relative prices, the type of govermment spending involved, how the govemment spending is to be financed, and whether the tax changes are presumed to be temponary or permanent.

Fiscal policy actions may also influesce wealth and interest rates in addition to income, the income effect presumably being what is referred to as the direct effect of fiscal actions on spending. Although monetary and fiscal chamels of influence are both complex, only monetary actions have fypically been viewed as operating within a black box.

\section{REMERVES}

[1] Ackley, Gardner. "The Wealth-Saving Relationship." The Journal of Political Economy 59(1951).

[2] Blinder, Alan S., and Solow, Robert M. "Does Fiscal Policy Matter?" Journal of Public Economics 2(1973).

[3] Board of Govenars of the Federal Reserve System. Equations In The MIT-PENN-SSRC Econometric Model Of The United States. (1973)

[4] Brown, A. I. "The Liquidity-Preference Schedules of the London Clearing Banks." Oxford Economic Papers 1(1938).

[5] Brunner, Karl. "The Report of The Commission On Money and Credit." The Journal of Political Econ. omy 69 (1961).

[6] _..... "The Role of Money and Monetary Policy." this Review 50(1968).

[7] _... "The 'Monetarist Revolution' in Monetary Theory." Weltwirtshaftliches Archiv 105 (1970).

[8] "A Survey of Selected Issues in Monetary Theory." Schweizerische Zeitschrift fï Volkswirt schaft und Statistik 107(1971).

[9] Brunner, Karl, and Meltzer, Allen H. "The Place of Financial Intermediaries In The Transmission of Monetary Policy." The American Economic Review $53(1963)$.

[10] "The Uses of Money: Money in the Theory of an Exchange Economy." The American Economic Review 61 (1971).

[11] . "Friedman's Monetary Theory." The Journal of Political Economy 80 (1972).

[12] __..... "Money, Debt, and Economic Activity." The Journal of Political Economy 80(1972).

[13] Cagan, Phillip. "Why Do We Use Money In Open Market Operations?" The Journal of Political Economy 66(1958).

[14] The Channels of Monetary Effects on Interest Rates. New York: National Bureau of Economic Research, 1972.
[15] Christ, Carl F. "A Model of Monetary and Fiscal Policy Effects on the Money Stock, Price Level, and Real Output." Joumal of Money, Credit and Banking 1(1969).

[16] "Econometric Models of the Financial Sector." Journal of Money, Credit and Banking 3(1971).

[17] Committee on the Working of the Monetary System. Repont. London: Her Majesty's Stationary Office, 1959.

[18] Crockett, Jean; Friend, Irwin; and Shavell, Henry. "The Impact of Monetary Stringency on Business Investment," Survey of Current Business 47(1967).

[19] Davis, Richard G. "The Role of the Money Supply in Business Cycles." Federal Reserve Bank of New York Monthly Review 50(1968).

[20] deleeuw, Frank, and Gramlich, Edward M. "The Channels of Monetary Policy." Federal Reserve Bulletin $55(1969)$.

[21] Ebersole, J. Franklin. "The Inflience of Interest Rates Upon Enterpreneurial Decisions In Business - A Case Study." Harvard Business Review 17 (1939).

[22] Eisner, Robert. "Factors Affecting The Level of Interest Rates: Part II." United States Savings and Loan League. Savings and Residential Financing: 1968 Conference Proceedings, 1968.

23] Ettin, Edward C. "A Qualitative Analysis of the Relationships Between Money and Income." Welt wirtschaftliches Archiv 96(1966).

[24] Fisher, Irving. Booms and Depressions: Some First Principles. New York: Adelphi Company, 1932.

[25] _... The Purchasing Power of Money: Its Determination And Relation To Credit Interest And Crises. rev. ed. New York: Reprints of Economic Classics, 1963.

[26] Friedman, Milton. "A Monetary and Fiscal Framework for Economic Stability." The American Economic Review 38 (1948). 
[27] . A Theory of the Consumption Function. New York: The National Burea of Economic Research, 1957.

[28] _.... "The Lag in Effect of Monetary Policy." The Joumal of Political Economy 69 (1961).

[29] "The Role of Monetary Policy." The American Economic Revieu 58(1968).

[30] "A Theoretical Framework for Monetary An" alysis." The Journal of Political Economy $78(1970)$.

[31] . "A Monetary Theory of Nominal Income." The Journal of Political Economy 79(1971).

[32] . . Comments on the Gritics." The Journal of Political Economy 80(1972).

[33] Friedman, Milton, and Meiselman, David, "The Relative Stability of Monetary Velocity and the Investment Multiplier In The United States," In Stabilization Policies, Commission on Money and Credit. Englewood Cliffs, New Jersey: Prentice-Hall, Inc., 1963.

[34] Friedman, Miiton, and Schwart, Anra J. "Money And Business Cycles." The Review of Economics and Statistics 45 (1963).

[35] Gramley, Lyle E., and Chase, Samuel B., Jr. "Time Deposits in Monetary Analysis," Federal Reserve Bulletin 51(1965).

[36] Gurley, John G. "The Radcliffe Report And Evidence: A Review Article." The American Economic Review $50(1960)$.

[37] Gurley, John G. and Shaw, Edward S, Money in a Theory of Finance. Washington, D.C.: The Brookings Institution, 1960.

[38] Haberler, Gottfried. Prosperity and Depression: A Theoretical Analysis of Cyclical Movements. 3d ed. Geneva: League of Nations, 1941.

[39] Hansen, Alvin H. "Economic Progress and Declining Population Growth." The American Economic Review 29(1939).

[40] Fiscal Policy and Business Cycles. New York: W. W. Norton \& Company, The., 1941.

[41] _....... "The Pigouvian Effect." The Journal of Polit:cal Economy 59(1951).

[42] Henderson, H. D. "The Significance of the Rate of Interest." Oxford Economic Papers I(1938).

[43] Hicks, J (ohn) R. "A Suggestion for Simplifying The Theory of Money." Economica 2(1935).

[44] ___ "Mr. Keynes and the Classics"; A Suggested Interpretation." Econometrica 5(1937).

[45] Value and Capital: An Inquiry Into Some Fundamental Principles of Economic Theory. $2 \mathrm{~d}$ ed. Oxford: The Clarendon Press, 1946.

[46] Critical Essays in Monetary Theory. Oxford: The Clarendon Press, 1967 .

[47] Hodgman, Donald R. Commercial Bank Loan Ard Investment Policy. Champaign, Illinois: Bureat of Economic And Business Research, 1963.

[48] Hume, David. Writings On Economics. Edited by Eugene Rotwein. Madison: The University of Wisconsin Press, 1970.
[49] Jaffee, Dwight M., and Modigliani, Franco. "A Theory and Test of Credit Rationing." The Ameri. can Economic Reviow 59 (1969).

[50] Kane, Edward J. "Fs There a Predilected Lock-In Effect?" National Tax Jounal 21(1968).

[51] Keynes, John Maynard. The General Theory of Employment Interest and Money. New York: Harcourt, Brace and Company, 1936.

[52] Laidler, David. "Expectations, Adjustment, and the Dynamic Response of Income to Policy Changes," Joumal of Money, Credit and Banking 5(1973).

[53] Leijonhafvad, Axel. On Ketynesian Economics and the Economics of Keynes: A Study in Monetary Theory. New York: Oxford University Press, 1968.

[54] Lerner, A. P. "The Burden of the National Debt." Income, Employment and Public Policy: Essays in Honor of Alvin H. Hansen. New York: W. W. Norton \& Company, Inc, 1948.

[55] Lindbeck, Assar. "The "New" Theory Of Credit Control In The United States." 2d ed. Stockholm Economic Studies Pamphlet Series I. Stockhom: Almqvist \& Wiksell, 1962.

[56] McCarthy, Michael D. The Wharton Quarterly Econometric Forecasting Model: Mark III. Philadelphia: University of Pennsylvania, 1972.

[57] Meade, J. E. and Andrews, P. W. S. "Summary of Replies to Questions on Effects of Interest Rates." Oxford Economic Papers 1(1938).

[58] Metaler, Lloyd A. "Wealth, Saving, And The Rate Of Interest." The Journal of Political Economy $59(1951)$

[59] Modigliani, Franco. "Liquidity Preference and the Theory of Interest and Money." Econonetrica 12 (1944).

[60] _... "The Monetary Mechanism And Its Interaction With Real Phenomena." The Review of Economics and Statistics 45 (1963).

61] "Monetary Policy and Consumption: Linkages via Interest Rate and Wealth Effects in the FMP Model." Federal Reserve Bank of Boston. Consumer Spending and Monetary Policy: The Linkages, 1971.

[62] ...... and Brumburg, Richard. "Utility Analysis and the Consumption Function: An Interprefation of Cross-Section Data." Post Keynesian Economics. Ed. ited by Kenneth K. Kurihara. New Brunswick, New Jersey: Rutgers University Press, 1954.

[63] Patinkin, Don. Money, Interest, and Prices: An Integration of Monetary and Value Theory. $2 \mathrm{~d}$ ed. New York: Harper \& Row, 1965.

[64] Pesek, Boris P., and Saving, Thomas R. Money, Wealth, And Economic Theory. New York: The Macmillan Company, 1967.

[65] Pigou, A. C. "The Value of Money." The Quarterly Journal of Economics 32(1917-1918).

[66] "The Classical Stationary State." Economic Journal 1943.

[67] Rasche, Robert H. "A Comparative Static Analysis of Some Monetarist Propositions." this Review $55(1973)$. 
[68] Roosa, Robert V. "Interest Rates and the Central Bank." Money, Trade, and Economic Growth: In Honor of John Henry Williams. New York: The Macmillan Company, 1951.

[69] Samuelson, Paul A. U.S., Congress, Joint Economic Committee. Monetary Policy and the Management of The Public Debt: Their Role in Achieving Price Stability And High-Level Employment. 82nd Congress, 2nd session, 1952.

[70] . "Money, Interest Rates And Economic Activity: Their Interrelationship In A Market Economy." The American Bankers Association. A Symposium on Money, Interest Rates And Economic Activity, 1967.

[71] Scitovszky, T. de. "Capital Accumulation, Employment and Price Rigidity." The Review of Economic Studies 8(1940-1941).

[72] Silber, William L. "'The St. Louis Equation: 'Democratic' and 'Republican' Version And Other Experiments." The Review of Economics and Statistics $53(1971)$.

[73] Smith, Paul E. "Lags in the Effects of Monetary Policy: Comment." The American Economic Review $62(1972)$.

174] Tammer, Emest J. "Lag in the Effects of Monetary Policy: A Statistical Investigation." The American Economic Revieu 59(1969).

[75] Tinbergen, Jan. Statistical Tesing of BusinessCycle Theories. Geneva: League of Nations, 1938.

[76] Tobin, James. "Relative Income, Absolute Income and Saving." Money, Trade and Economic Growth: In Honor of John Henry Williams. New York: The Macmillan Company, 1951.

[77] "Money, Capital, And Other Stores of Value." The American Economic Review 51 (1961).

[78] "Commercial Banks as Creators of "Money." Banking and Monetary Studies. Edited by Deane Carson. Homewood, Illinois: R. D. Irwin, Inc, 1963.
[79] "An Essay On Principles of Debt Management," In Fiscal and Debt Management Policies, Commission on Money and Credit. Englewood Cliffs, New Jersey: Prenticem Hall, Inc, 1963.

[80] . "Monetary Semantics." Targets and Indicators of Monetary Policy. Edited by Karl Brunner. San Francisco: Chandler Publishing Company, 1969.

[81] _...... "A General Equilibrium Approach To Mone tary Theory." Jotrnal of Money, Credit and Banking 1 (1969).

[82] . "Money and Income: Post Hoc Ergo Propter Hoc?" The Quarterly Journal of Economics 84(1970)

[83] _...... "Rebuttal." Federal Reserve Bank of Boston. Consumer Spending and Monetary Policy: The Linkages, 1971.

[84] Tobin, James, and Brainard, William C. "Pitfalls In Financial Model Building." The American Economic Review 58(1968).

185] Tobin, James, and Dolde, Water. "Wealth, Liquidity and Consumption." Federal Reserve Bank of Boston. Consumer Spending and Monetary Policy: The Linkages, 1971.

[86] Tooke, Thomas. A History of Prices and of the State of the Circulation from 1792 to 1856 . Lon don: P. S. King and Son, Ltd., 1928.

[87] Tucker, Donald P. "Dynamic Income Adjustment to Money-Supply Changes." The American Eco. nomic Review 56(1966).

[88] Warburton, Clark. Depression, Inflation, And Monetary Policy: Selected Papers, 1945-1953. Baltimore: The John Hopkins Press, 1966.

[89] Wicksell, Knut. Lectures on Political Economy: Money. Vol. 2. Edited by Lionel Robbins. London: Routledge \& Kegan Paul Litd, 1950.

[90] . Interest and Prices: A Study of The Catses Regulating The Value of Money. Translated by R. F. Kahn. New York: Reprints of Economic Classics, 1962. 